\title{
Macroeconomic Variables Volatility in the Nigerian Stock Market; An Empirical Analysis
}

\author{
Izunobi, Anthony Okechukwu; Nzotta, Samuel Mbadike; Ebiringa, Oforegbunam \\ Thaddeus; Akujuobi Aghalugbulam Bonaventure Chidiebere ; Chigbu Emmanuel ezeji
}

Department of Financial Management Technology

Federal University of Technology, Owerri, Nigeria

\begin{abstract}
The study employed the GARCH (1,1) and E-GARCH model techniques to establish that three macroeconomic variables interest rate, inflation rate and stock market return are volatile, the objective of this study is to determine the magnitude and behavioural pattern of these macroeconomic variables, using monthly series data from 1995-2014.This study examined macroeconomic variables volatility in the Nigerian stock market. It was established that inflation rate and interest rate were volatile and moved in clusters otherwise known as volatility Clustering. It was also observed that the volatility of inflation rate and interest rate returned to the mean of the variance equation earlier than the volatility in the stock market returns take in reverting to the equilibrium. We thus, conclude that there is high and persistent volatility in the stock market returns. Inflation and interest rate was also found to have significant impact on stock market returns volatility.
\end{abstract}

Keyword: Volatility Clustering, Macroeconomic Variables, Stock Market Returns

\section{INTRODUCTION}

The stock market plays an important role in achieving macroeconomic objectives, thus the long term economic growth of a nation depends significantly on how well the stock market function. However, volatility in the stock market is an issue of great concern. The existence of which may undermine the ability of the stock market to play its primary role of efficiently mobilizing and allocating recourses for investment. Volatility refers to sharp fluctuation in the price of a financial asset or market within a short period of time. Stock market volatility can be defined as the possibility that a given stock will experience a drastic rise or fall in value within a predetermined time frame Okpara (2011).

Rano (2010) states that excess volatility breads uncertainty which hampers effective performance of the financial sector as well as the entire economy. The main problem of price fluctuations affecting stock the market is the destructive impact of excess volatility which causes market crashes and crisis Goudarz and Ramanarayanon (2011). Very high stock market volatility induces instability in the capital market, destabilizes the value of currency and hampers international trade and finance Blawmik (2013).

Petro (2011) on the other hand posit that the higher the stock market volatility, the lower the efficiency of the price signal in allocating investment resources especially in less developed countries. High stock market volatility has an adverse effect on investor trading behaviour. Investors evaluate the price signal of a stock already in their portfolio before trading the stock in their possession.

High volatility influences investors to make changes at may lead to long term fall in the capital inflow from foreign and domestic investors. This was experienced in Nigeria during the global economic meltdown in 2008. The meltdown has continued to have adverse effect on the Nigerian economy.

High stock market volatility has great impact on the economic condition of a country, financial managers, firms, investors as well as other stakeholders Mushtag et al (2011). Many investors realize that the stock market is a volatile place to invest their funds, the daily, quarterly and annual price movement can be dramatic, but it is this volatility that also generates the market returns which investors experience.

The selection of interest rates and inflation rates is based on the spontaneous response their volatility generates in the stock market returns. Figure 1.below shows stock market returns in Nigeria. 


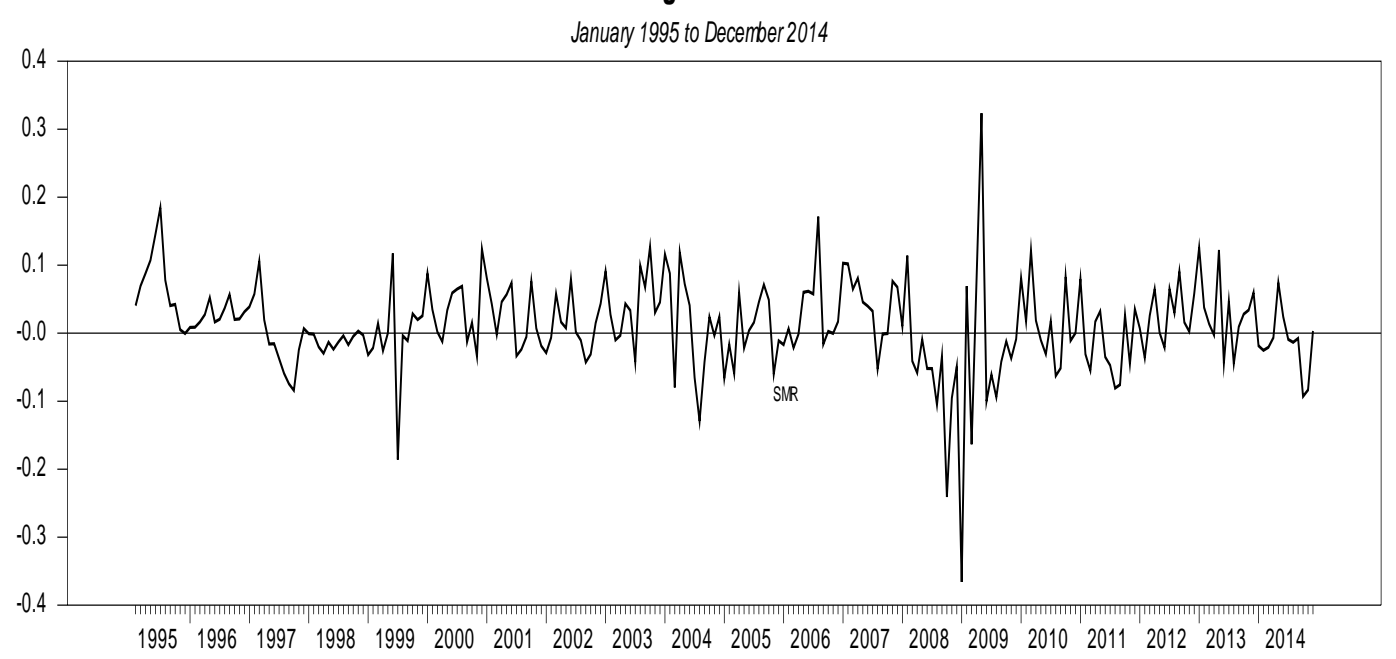

Fig1. Nigeria Market Returns January 1995 to December2014

From fig 1, it can be seen that the trend moved in quick succession, indicating that the presence of volatility in stock market returns in Nigeria. Worthy of note is the $3^{\text {rd }}$ quarter of 2008; the spikes reached its highest points of -3.5 and 3.5. This was the period of the global financial crisis. Many investors realized that the stock market is a volatile place to invest their funds. The daily, quarterly and annual movements can be dramatic, but it is this volatility that also generates the market returns investors experience. This study explained how volatility in stock market returns, interest rate and inflation affects investors' returns and how to take advantage of it.

Volatility is a measure of dispersion around the mean or average return of a security. One way to measure volatility is by using the standard deviation, which explains how tightly the price of a stock is grouped around the mean or moving average (MA). When the prices are tightly bunched together, the standard deviation is small. When the price movements are spread apart, a relatively large standard deviation occurs.

\section{Research Problem ANd ObJective}

The stock market is the engine of growth, which efficiently allocates resources to mobilize and allocate resources to entities seeking expansion. It serves as engine of growth and development in both developed and developing economies. The existence of excessive market return volatility in stock market may hinder stock market from playing its role properly. Suleiman (2011) states that volatility may impair the smooth functioning of the stock market and negatively affect economic performance

According to Verma and Mahajan (2012), if the country's stock market is highly volatile, the probability of both domestic and foreign investors to invest in such market is going to be less. This is due to the fact that returns in such markets are liable to higher risk and may affect the economic growth of that country. Schwert (1989) suggests that stock market volatility could be used as an additional factor in assessing the state of the economy. The recent global financial crisis that occurred in 2008, which was mainly caused by the industrialized economies, affected the Nigerian stock market negatively, resulting in significant decreases in economic activity and losses amongst institutional investors and other stake holders. Thus one can conclude that stock market volatility has significant impact in economic growth of both developed and less developed countries like Nigeria, Oseri and Nwosu (2011).

According to Bhowmik (2013), some recent studies show that a rise in stock market volatility depresses economic activity and output. Suleiman (2011) also stated that stock market volatility affects business investment and economic growth.

Petro (2011) stated that the higher the stock market volatility in less developed countries, the less the efficiency of the price signal in allocating investment resources. Stock market volatility affects trading behaviour of investors. Higher volatility in stock prices has adverse effect on the economy. It 
influences investors to make changes in their investment decisions which may lead to fall in long term capital inflow from foreign and domestic investors as experienced in the Nigeria capital market during the global economic meltdown in 2008.

Very high stock market volatility induces instability in the capital market, destabilizes the value of domestic currency and hampers international trade and finance. Suleiman (2011) also stated that stock market volatility affects business investment and economic growth. Petros, (2011) stated that the higher the stock market volatility in less developed countries, the less the efficiency of the price signals in allocating investment resources. Stock market volatility affects the trading behavior of investors. Investors evaluate the volatility of the stock already in their portfolio before selling the stock currently in their possession. Higher volatility in stock prices may adversely affect the economy if not well managed. It influences investors to make changes in their investment decision, which may lead to a fall in the long term capital flow from foreign and domestic investors. The impact of interest rate and inflation rate fluctuations on stock market return volatility cannot be over emphasized, hence the need for this study which seek to validate the following hypotheses:

$\mathrm{H}_{01}$ : There is no volatility clustering in the Nigeria stock market returns

$\mathrm{H}_{02}$ : There is no significant volatility clustering in the Interest rates

$\mathrm{H}_{03}$ : There is no significant volatility clustering in the Inflation rates

This study thus investigates the extent to which empirical evidence exist to suggest that volatility occur in inflation rates, interest rate and stock market returns in Nigeria.

\section{THEORETICAL Frame WORK AND EMPIRICAL LiTERATURE}

Andrew Thrasher (2017) in his paper forecasting a volatility, asserts that it is the suppression of volatility returns dispersions that has in the past led to higher market volatility. Thrasher noted that missing the ten worst day's stock market decline over that period would have boosted annualized returns by over $6 \%$ from $17.89 \%$ to $24.17 \%$, asuming one were to miss both the ten worst and ten best stock market sessions; returns would jump to $20.31 \%$ with significantly lower volatility. In his analysis, Thrasher also notes that periods of market high and low points occur in a tight pattern. Nearly half of the worst and best performing stock market days were no more than 12 days apart.

Furthermore thrash believes that dispersion of prices, as measured by daily standard deviation of VIX and VXIX act as a more accurate and timely method of forecasting spikes in the volatility index. This method provides an early warning signal of a potential on coming "volatility tsunami" that can have negative implications for an investment portfolio and allows for potential to make profit from the rising tide if VIX.

Drimus and Farkas (2012) noted that the average daily volume for VIX options in 2011 has almost doubled compared to 2010 and is nearly 20 times larger than in the year of their launch which is 2006 . Zakamalin (2006) states, the median and average duration for rising and falling are not equal. The time span for declines in volatility surpass the length of rising volatility by a factor 1.4 and the resulting impact on equity market is asymmetric with a perceived over reaction to rising volatility compared to decling volatility. According to Bhowmik, (2013), some recent studies show that a rise in stock market volatility depresses economic activity and output (Onwukwe, et al; 2011; Emenike and Aleke, 2012; Babatunde, 2013)

Volatility tends to decline as stock market returns rise and increase as stock market falls; when volatility increases, risk increases and returns decreases. Risk is represented by the dispersion of the returns around the mean, the larger the compound return.

One of the theories that support this study is the efficient market hypothesis which has the weak, semi strong and strong forms

The weak form states that the stock market show all past information about the price signals. It cannot be used to predict future stock price signals by analyzing the historical prices and achieve a performance better than the market index. This is due to the fact that the stock market has no memory, and most importantly, the market has already incorporated past information about the security prices in the current market prices. 
The semi-strong form states that stock price signals reflect publicly available information, which by implication assumes that an investor can outperform the market by analyzing the existing company related information and other relevant information in the financial statement/news. Such publicly available information is already incorporated in the current stock price signals

The strong form on the other hand believes that stock market prices show all published, unpublished and private information. This is perceived to be a strong assertion, but empirical studies do not have valid evidence to show that people with insiders' information can outperform the market.

However, investment in securities is a veritable medium of transforming savings into economic growth and development, it is worthy to note that the future of economic development in Nigeria depends on the expansion of the stock market.

The nexus between stock market performance and economic growth has often been a source of controversy among analysts, based on their study of the developed and emerging markets. It is believed that the financial structure of a firm which is a mix of debt and equity changes as economies develop. The tilt is however more towards equity financing than debt financing through the stock market.

On the other hand, the stock market contributes to economic growth through the specific services it performs directly or indirectly. The functions of the stock market are mobilization of savings, risk diversification, creation of liquidity, acquisition and dissemination of information, and enhanced incentive for corporate control. Improving the efficiency and effectiveness of these functions, through prompt delivery of their services is critical for improving the rate of economic growth.

However, the government and the private sector would require long-term capital for economic growth. For instance, firms would need to build new factories, expand existing ones, or buy new equipment. Government, on the other hand, would also require funds for the provision of infrastructure. All these activities require long-term capital, which is provided by a well-functioning capital market.

Park and Ratti (2000) analyzed the dynamic interdependencies among real economic activity, inflation, stock returns, and monetary policy, using a VAR model. They used monthly U.S data from 1995-1998 in their study, their findings show that shocks due to monetary tightening generated statistically significant movements in inflation and expected real stock returns, and that these movements are not found in opposite directions.

Wongbangpo and Sharma (2002) examined the relationship between the stock returns for the ASEAN-5 countries and five macroeconomic variables and concluded that in the long term, all five stock price indexes were positively related to growth in output and had negative relationship with the aggregate price level. Mukhopadhyay and Sarkar (2003) examined a systematic analysis in the Indian stock market returns prior to and after market liberalization and the influence of macroeconomic factors on returns. The findings suggests that for the post-liberalization period (since 1995), real economic activity, inflation, money supply growth, foreign direct investment, and the NASDAQ stock indices were significant in explaining variations in Indian stock returns.

The nature and economic significance of the relationship between stock market development and growth vary according to a country's level of economic development with a lager impact in less developed economies (Abugri, Benjamin, 2008). The proponents of positive relationship between stock market development and economic growth base their argument on the fact that the stock market aids economic growth and development through the mobilization and allocation of savings, risk diversification, liquidity creation and corporate governance improvement among others.

Chinzara and Aziakpono (2009) found that stock returns and volatility in South Africa have linkage with major world stock markets with Australia, China and U.S having the most impacts and that volatility exhibits asymmetry and stability over time, and that there is lack of evidence of the risk premium hypothesis.

Alagidede and Panagiotidis (2010) investigated the relationship between the stock prices and inflation for selected African stock markets. For South Africa, their findings showed that the elasticity of the stock price with respect to the consumer price is 2.264 and that the stock price shows a transitory 
negative response to the consumer price in the short run and a positive response on the long run. Hence, stocks are a hedge against inflation on the long run.

Arjoon, Botes, Chesang and Gupta (2010) investigated the relationship between stock price and inflation for South Africa. They found that real stock prices are not affected by a permanent change in the inflation rate on the long run

Xiufang Wang (2010) examined the time-series relationship between stock market volatility and macroeconomic variable volatility for China using exponential generalized autoregressive conditional heteroskedasticity (EGARCH) and lag-augmented VAR (LA-VAR) models and their finding showed that there is a bilateral relationship between inflation and stock price, while a unidirectional relationship exists between the interest rate and stock price, with the direction from stock price to the interest rate. However, a significant relationship between stock price and real GDP was not found. Our study however is related to theirs, but the structure of Nigerian economy is quite different from theirs. Even China today is one of the fast growing countries in the world in terms of economic activities and also is classified as an emerging country whereas Nigeria is still a developing nation.

Gupta and Modsis (2011) estimated the predictive power of selected macroeconomic variables for South Africa. Their result show that for in-sample forecasts, interest rates, the money supply and world oil production growth have some predictive power in the short run, than for out-of-sample forecasts, interest rates and the money supply exhibit short-run predictability, and that the inflation rate shows a strong out-of-sample predictive power.

Chinzara (2011) examined macroeconomic uncertainty and stock market volatility for South Africa. His study indicated that stock market volatility is significantly affected by macroeconomic uncertainty. He found that financial crisis raise stock market volatility, and that volatility in exchange rates and short-term interest rate are the most influential variables in affecting stock market volatility whereas volatility in oil prices, gold prices and inflation play minor roles in affecting stock market volatility.

John and Owusu-Nantwi (2011) investigated the relationship between Macroeconomic Variables and Stock market Returns in Ghana using Full Information Maximum Likelihood Estimation Procedure. Inflation rate, exchange rate and treasury bills were considered as the major macroeconomic variables and serves as the independent variables, while stock market returns were proxied as all share indexes. It was found that inflation rate had a positive significant effect on stock market returns, while exchange rate and Treasury bill had negative effect on stock market returns. The study failed to incorporate all the macroeconomic variables in their study which created a research gap.

Robert and Gay (2008) studied the effect of Macroeconomic Variables on Stock Market Returns for four Emerging Economies: Brazil, Russia, India and China using Box-Jenkins ARIMA model. The result indicated that no significant relationship was found between respective exchange rates and oil prices on the stock market index prices of either BRIC countries, which may influence of other domestic and international macroeconomic factors on stock market returns, warranting further research. Adamopoulos (2010) investigated the Stock Market and economic growth in Germany using Vector Error Correction Model (VECM). All share indexes were used as dependent variable, while GDP and inflation rate were used as independent variables. The results of the Granger causality tests revealed that there is a unidirectional causality between stock market development and economic growth with direction from stock market development to economic growth.

Oseni and Nwosu (2011) examined the relationship between stock market volatility and macroeconomic variables volatility in Nigeria. They found that a bi-causal relationship exists between stock market volatility and real GDP volatility, and there is no causal relationship between stock market volatility and the volatility in interest rate and inflation rates. Their study recommended that in order to reduce stock market volatility, Government should take pro-active measures to stabilize the market through tapping the growing interest of the general public in the market by increasing supply of shares.

Izuchukwu, Ifurueze and Chude (2015) studied the impact of some selected macroeconomic variables and stock market returns in Nigeria. The result of their study indicates that the level of economic growth over the years have significant positive impact on stock market returns, while inflation and monetary rate show negative significant impact on stock market returns in Nigeria. Their study 
revealed that a decrease in inflation and monetary policy rate will improve the performance of the Nigerian stock market in both the long and short runs. The researchers recomended that the Nigerian stock market should be made more attractive to potential larger number of small investors who wish to depend on long run term investment during retirement; this would enhance the growth of gross domestic products.

\section{Methodology}

The stock market returns used the All Share Index (ASI) of the Nigerian stock market as its proxy; inflation used the Consumer Price Index (CPI) as proxy and interest rates used Monetary Policy rates (MPR).This study used the GARCH and EGARCH models to analyze the data collected. The GARCH model has been known for its high precision, and its ability to assign different weights on the series data The General Auto Regressive Conditional Heteroscedasticity model (GARCH) was used to test the set hypothesis. The GARCH and EGARCH models were used to test $\mathrm{H}_{01} ; \mathrm{H}_{02}$ and $\mathrm{H} 03$,.

The two main methods used by the paper are GARCH and EGARCH for determining volatility. The GARCH and EGARCH models were used in this study to evaluate the volatility of the stock market returns, inflation and interest rates. The GARCH model performs better than the multiple regression model due to its ability to assign varying weights to the series data as against the multiple regression model that assigns equal weights to the series data.

\section{Specific GARCH Parameters Used Include:}

$\omega$ - Average weight of long run variance.

$\alpha$ - Variance predicted in the previous period.

$\beta$ - New information in the period not available when previous forecast was made.

$\mu-$ Variance predicted in the previous period

Coefficients $(\delta)$ - Numbers attached to equal parameters used in the model weights.

$\mathrm{SMR}_{\mathrm{t}}-$ Stock market returns

$\mathrm{SMR}_{\mathrm{t}}=\omega_{0}+\alpha_{1} \mu_{\mathrm{t}-1}^{2}+\beta_{1} \delta_{\mathrm{t}-1}^{2}$

Where $\omega \geq 0, \alpha \geq 0, \beta \geq 0$ and $\alpha_{1}+\beta_{1} \geq 0$

This model shows that the next period forecast of variance is a blend of the last forecast and last period's squared returns.

\section{The Specific GARCH Models}

$\theta-$ Mean variance

$\mathrm{SMR}_{\mathrm{t}}=\theta+\mu_{\mathrm{t}}$

$\delta_{\mathrm{t}}^{2}=\omega_{0}+\alpha_{1} \mu_{\mathrm{t}-1}^{2}+\beta_{1} \delta_{\mathrm{t}-1}^{2}$

Equation 1 in the model is the mean equation while equation 2 represents the Volatility clustering in the stock market returns

IR - Interest rates

$\mathrm{IR}_{\mathrm{t}}=\theta+\mu_{\mathrm{t}}$

$\mathrm{IR}_{\mathrm{t}}=\omega_{0}+\alpha_{1} \mu_{\mathrm{t}-1}^{2}+\beta_{1} \delta_{\mathrm{t}-1}^{2}$

Equation 3 in the model is the mean equation, while equation 4 represents the volatility clustering in interest rates.

$\mathrm{INF}_{\mathrm{t}}-$ Inflation rates

$\mathrm{INF}_{\mathrm{t}}=\theta+\mu_{\mathrm{t}}$

$\delta_{\mathrm{t}}^{2}=\omega_{0}+\alpha_{1} \mu_{\mathrm{t}-1}^{2}+\beta_{1} \delta_{\mathrm{t}-1}^{2}$

Equation 5 in the model is the mean equation, while equation 2 represents the Volatility clustering in inflation rates 
The ARCH coefficient $\alpha$ is the parameter which measured leverage effect (i.e that variances in the previous period has influence on the current period variances).

The GARCH coefficient $\beta$ measures the forecast variances from the last period.

$\alpha+\beta$ measures persistence of shock volatility.

If $\alpha+\beta \leq 1$ implies a tendency for volatility to decay over time.

If $\alpha+\beta \geq 1$ implies volatility persistence over time.

The presence of high volatility in a stock market returns is a sign of market inefficiency.

$\mathrm{R}^{2}$ was used to check the fitness of the models.

T-test was used for testing this model. If $t$ calculated $>t$ tabulated, we reject the null hypothesis and accept the alternative at $5 \%$ degree of freedom.

This study focused on finding out whether volatility clustering occurs in the Nigerian stock market return. The GARCH model was used to evaluate volatility clustering and persistence. P-values were used to check the fitness of the GARCH and E-GARCH models used in the study. The GARCH and EGARCH models have previously been used by Okpara and Nwezeaku (2010), Oseni and Nwosa (2011), Emenike and Odili, (2014). The outcome of these studies showed the relationship between stock returns volatility and market performance.

\section{RESUlTS AND DiscuSSION}

The data set employed in this study comprises of inflation rates, interest rates and stock market returns of Nigeria, covering the period, 1995-2014.

Data Estimation: We carried out the test for stationarity on the various variables employed in the work, including Stationarity Test for Stock Market Returns (ASI).The spikes on the graph as shown in figure 4.1 below revealed that the volatility will revert to equilibrium over a long period of time. Thus there is evidence of non-stationarity However, from fig. 2, it can be observed that one spike is almost 1 and the rest of the spikes are almost zero i.e. same with the mean This is also known as white noise.

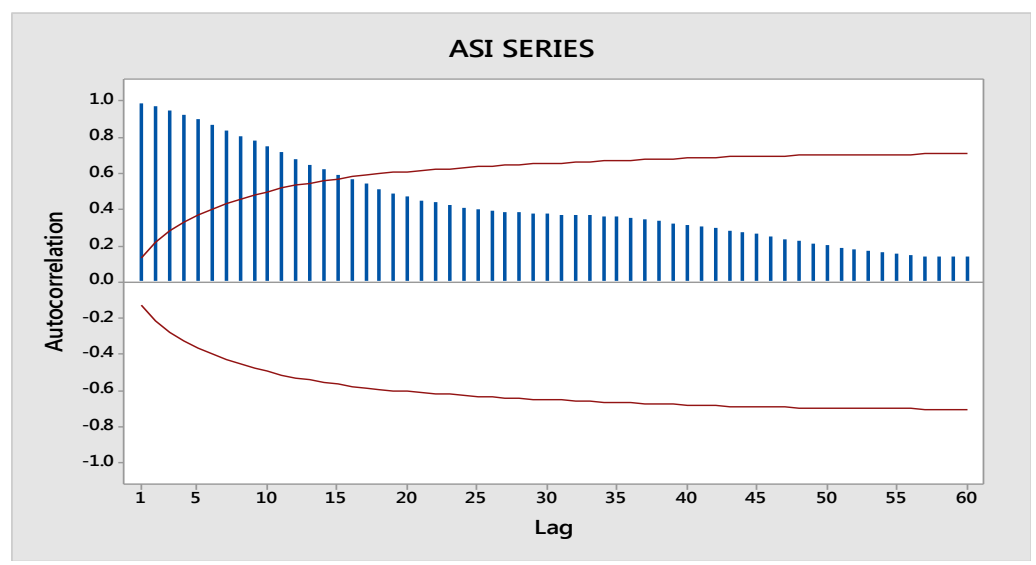

Fig2. Stock Market Returns Auto Correlation Function

On this premise therefore, non-stationary was confirmed, only to become stationary at first difference.

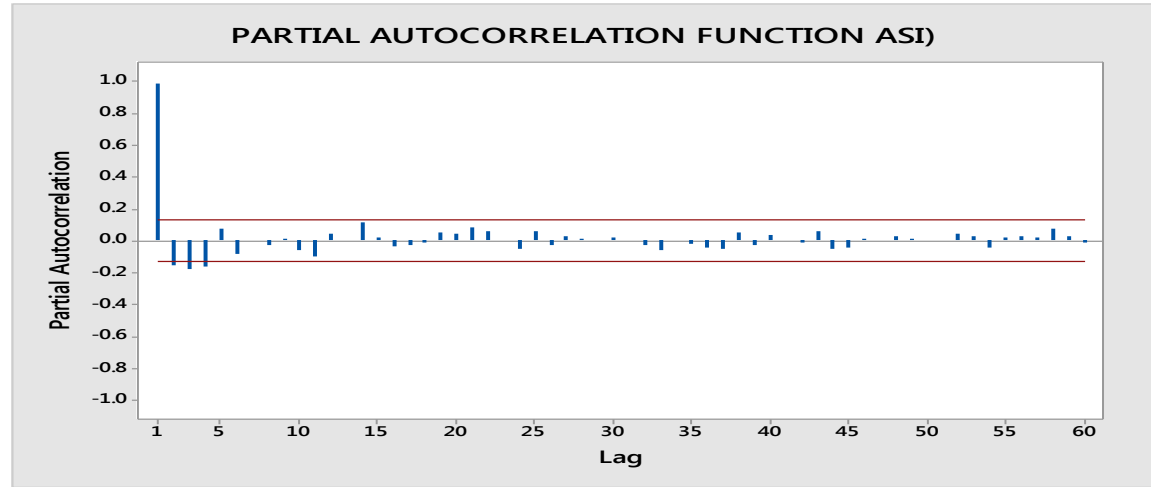

Fig3.The Partial Auto Correlation Function Graph for Stock Market Returns 


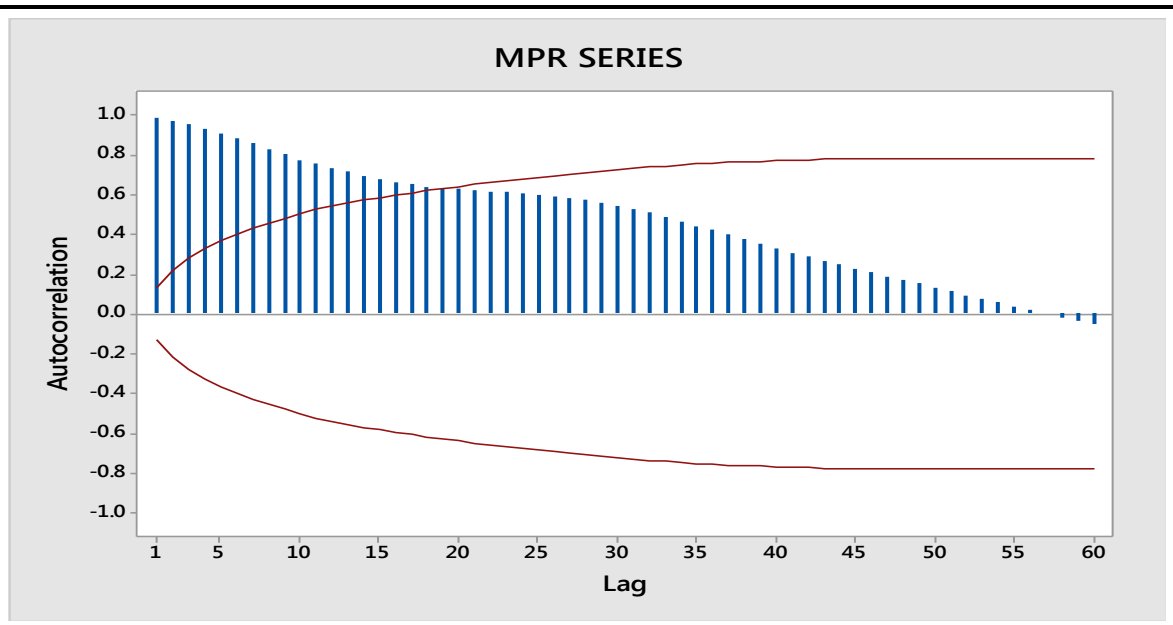

Fig4 The Autocorrelation Graph of Interest Rate.

The spikes on the fig 4 decayed over a long period which implies that it will revert to equilibrium after a long period. The data set became stationary after the first difference.

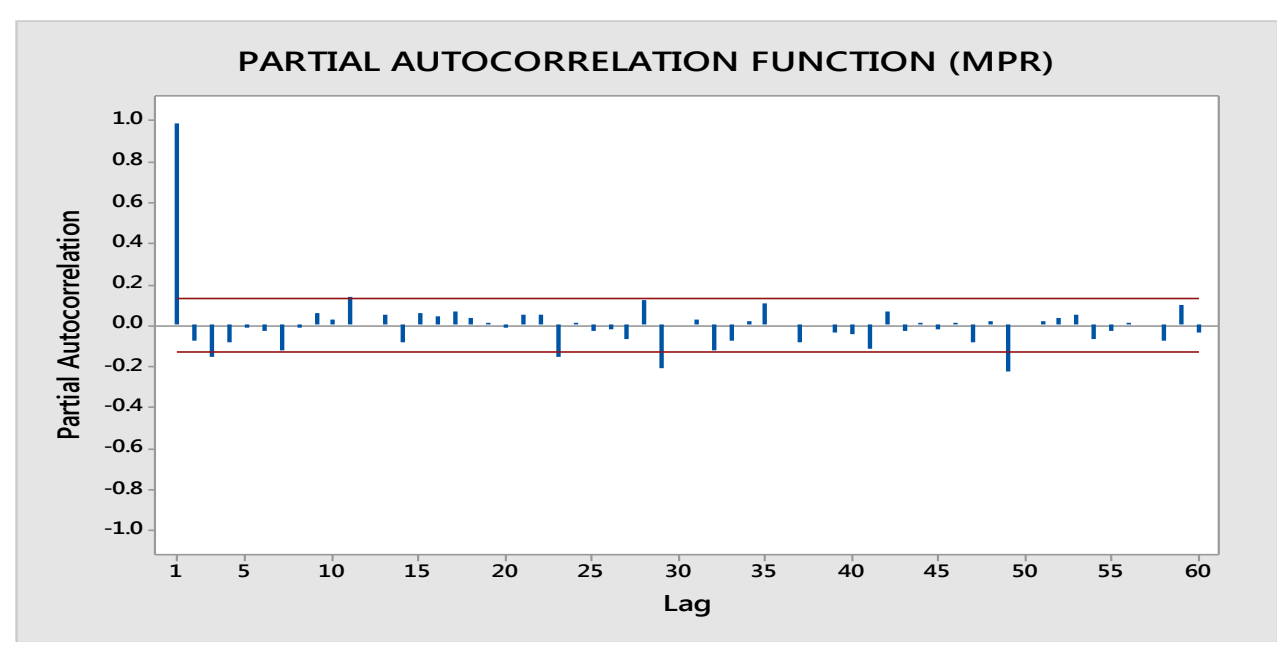

Fig5.The Partial Autocorrelation Function Graph for Interest Rate.

From figure 5 one spike is almost 1 and the rest of the spike is fluctuating between -0.3 and 0.2.This shows non stationary. The values are very close to the mean, which is zero. This is also known as white noise

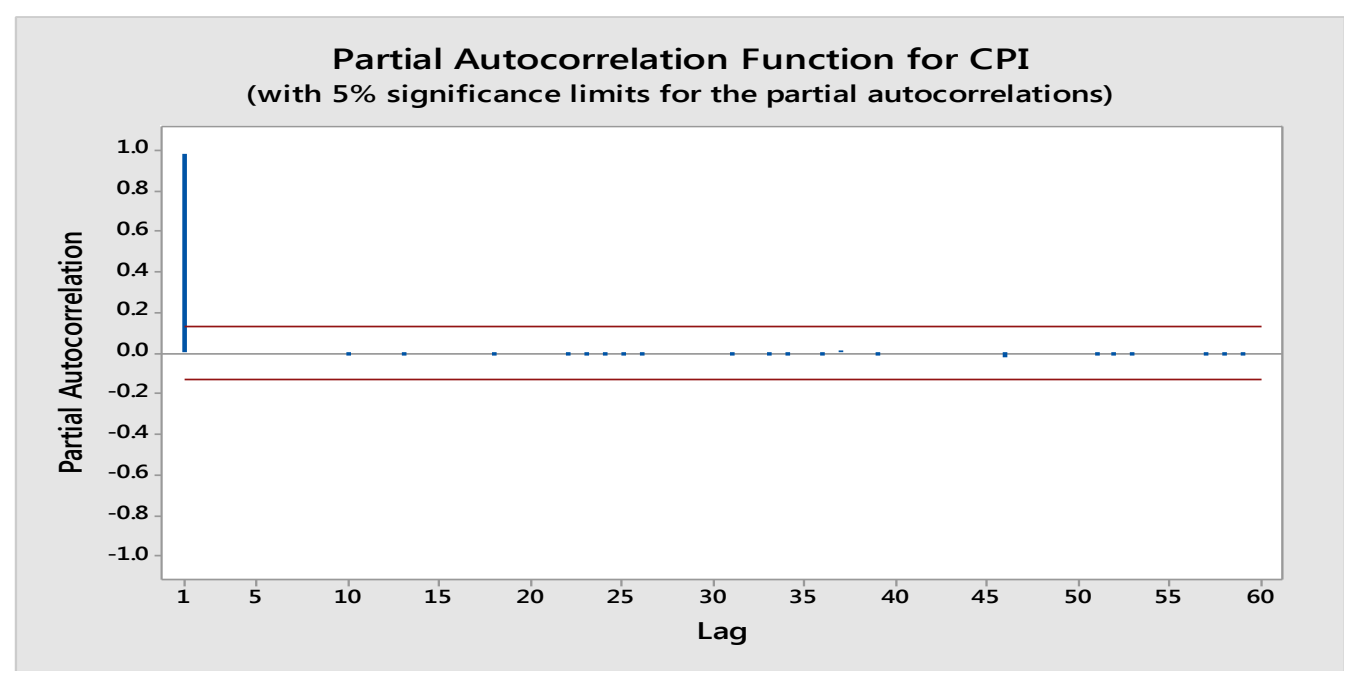

Fig6.The Partial Autocorrelation Function graph for Inflation.

From fig6 one spike is almost 1 and the rest of the spikes are almost zero, this shows non stationarity, almost same with the mean, this is white noise, however, tuning stationary at first difference like the other two variables. 
Table1. Garch Model for (Asi) After Differencing

\begin{tabular}{|c|c|c|c|c|}
\hline \multicolumn{5}{|c|}{$\begin{array}{l}\text { Dependent Variable: D(ASI) } \\
\text { Method: ML ARCH - Normal distribution (BFGS / Marquardt steps) } \\
\text { Date: 09/07/16 Time: } 22: 50 \\
\text { Sample (adjusted): } 1995 \mathrm{M} 02 \text { 2014M12 } \\
\text { Included observations: } 239 \text { after adjustments } \\
\text { Convergence achieved after } 27 \text { iterations } \\
\text { Coefficient covariance computed using outer product of gradients } \\
\text { Pre sample variance: back cast (parameter }=0.7) \\
\text { GARCH }=\mathrm{C}(2)+\mathrm{C}(3)^{*} \operatorname{RESID}(-1)^{\wedge} 2+\mathrm{C}(4) * \mathrm{GARCH}(-1)\end{array}$} \\
\hline Variable & Coefficnt & Std. Error & z-Statistic & Prob. \\
\hline \multirow[t]{2}{*}{$\mathrm{C}$} & 144.8708 & 27.14728 & 5.336477 & 0.0000 \\
\hline & \multicolumn{4}{|c|}{ Variance Equation } \\
\hline $\begin{array}{l}\mathrm{C} \\
\operatorname{RESID}(-1)^{\wedge} 2 \\
\operatorname{GARCH}(-1)\end{array}$ & $\begin{array}{l}3808.041 \\
0.460889 \\
0.682731\end{array}$ & $\begin{array}{l}3417.804 \\
0.086360 \\
0.046123\end{array}$ & $\begin{array}{l}1.114178 \\
5.336828 \\
14.80235\end{array}$ & $\begin{array}{l}0.2652 \\
0.0000 \\
0.0000\end{array}$ \\
\hline $\begin{array}{l}\text { R-squared } \\
\text { Adjusted R-squared } \\
\text { S.E. of regression } \\
\text { Sum squared resid } \\
\text { Log likelihood } \\
\text { Durbin-Watson stat }\end{array}$ & $\begin{array}{l}-0.000027 \\
-0.000027 \\
1804.892 \\
7.75 \mathrm{E}+08 \\
-1984.714 \\
1.508026\end{array}$ & $\begin{array}{l}\text { Mean d } \\
\text { S.D. de } \\
\text { Akaike } \\
\text { Schwar } \\
\text { Hannan }\end{array}$ & $\begin{array}{l}\text { nt var } \\
\text { t var } \\
\text { iterion } \\
\text { ion } \\
\text { criter. }\end{array}$ & $\begin{array}{l}135.4471 \\
1804.867 \\
16.64195 \\
16.70014 \\
16.66540\end{array}$ \\
\hline
\end{tabular}

From table1 the ARCH and GARCH coefficients are positive. Here they have the required sign. The coefficients add up to approximately 1.In the table 1 the sum of the $\alpha 0.460889+\beta 0.682731=1.14$, implying that the stock market returns in the Nigeria stock market is volatile because the of sum $\alpha$ and $\beta$ is $>$ 1.Probability: P-value was tested at $5 \%$ and the result in the model show the level at significance at 0.0000 which is $<0.05$, thus we reject $\mathrm{H}_{0} 1$, which states that there is no volatility clustering in the Nigeria stock market returns and accept $\mathrm{H}_{\mathrm{A}} 1$ which affirms that there is volatility clustering in the Nigeria stock market returns. The stock market returns data ASI for the period under review proved to be non-stationary, but it was found to be stationary at first difference.

\subsection{Volatility Clustering in Interest Rates}

In order to test this hypothesis, the study used the results of $\operatorname{GARCH}(1,1)$ and $\operatorname{EGARCH}(\mathrm{q}, \mathrm{p})$ models as presented in tables 2 and 3.

Table2. Garch Model Result for Interest Rates (Mpr)

\begin{tabular}{|c|c|c|c|c|}
\hline \multicolumn{5}{|c|}{$\begin{array}{l}\text { Dependent Variable: D(MPR) } \\
\text { Method: ML ARCH - Normal distribution (BFGS / Marquardt steps) } \\
\text { Date: 09/08/16 Time: 06:35 } \\
\text { Sample (adjusted): 1995M02 2014M12 } \\
\text { Included observations: } 239 \text { after adjustments } \\
\text { Failure to improve likelihood (non-zero gradients) after } 127 \text { iterations } \\
\text { Coefficient covariance computed using outer product of gradients } \\
\text { Pre sample variance: back cast (parameter }=0.7) \\
\text { GARCH }=\mathrm{C}(2)+\mathrm{C}(3)^{*} \mathrm{RESID}(-1)^{\wedge} 2+\mathrm{C}(4) * \mathrm{GARCH}(-1)\end{array}$} \\
\hline Variable & Coefficient & Std. Error & z-Statistic & Prob. \\
\hline \multirow[t]{2}{*}{$\mathrm{C}$} & -0.002784 & 0.033842 & -0.082258 & 0.9344 \\
\hline & \multicolumn{4}{|c|}{ Variance Equation } \\
\hline $\begin{array}{l}\mathrm{C} \\
\operatorname{RESID}(-1)^{\wedge} 2 \\
\operatorname{GARCH}(-1)\end{array}$ & $\begin{array}{l}0.151658 \\
-0.023181 \\
0.591644\end{array}$ & $\begin{array}{l}0.073023 \\
0.001306 \\
0.204476\end{array}$ & $\begin{array}{l}2.076835 \\
-17.75534 \\
2.893457\end{array}$ & $\begin{array}{l}0.0378 \\
0.0000 \\
0.0038\end{array}$ \\
\hline
\end{tabular}




\begin{tabular}{|llll|}
\hline \hline R-squared & & & \\
Adjusted R-squared & -0.000001 & Mean dependent var & -0.002092 \\
S.E. of regression & -0.000001 & S.D. dependent var & 0.605469 \\
Sum squared resid & 0.605469 & Akaike info criterion & 1.814069 \\
Log likelihood & 87.24907 & Schwarz criterion & 1.872252 \\
Durbin-Watson stat & -212.7812 & Hannan-Quinn criter. & 1.837515 \\
\hline \hline
\end{tabular}

From table 2 the p- values are all significant at 0.05 level, the coefficients of the $\alpha$ and $\beta$ parameters are -0.023181 and 0.591644 respectively. The result did not satisfy the conditions for the GARCH model of non-negative value thus we used EGARCH model to test the hypothesis.

Table3. Egarch Model Result for Interest Rates (Mpr)

\begin{tabular}{|c|c|c|c|c|}
\hline \multicolumn{5}{|c|}{$\begin{array}{l}\text { Dependent Variable: D(MPR) } \\
\text { Method: ML ARCH - Normal distribution (BFGS / Marquardt steps) } \\
\text { Date: 09/08/16 Time: 06:41 } \\
\text { Sample (adjusted): 1995M02 2014M12 } \\
\text { Included observations: } 239 \text { after adjustments } \\
\text { Convergence achieved after } 39 \text { iterations } \\
\text { Coefficient covariance computed using outer product of gradients } \\
\text { Presample variance: backcast (parameter = 0.7) } \\
\text { LOG(GARCH) = C(2) + C (3)*ABS(RESID }(-1) / \text { SQRT }(\text { GARCH(-1))) + C(4) } \\
\quad \text { *RESID }(-1) / @ S Q R T(G A R C H(-1))+C(5) * \operatorname{LOG}(\operatorname{GARCH}(-1))\end{array}$} \\
\hline Variable & Coefficnt & Std. Error & z-Statistic & Prob. \\
\hline \multirow[t]{2}{*}{$\mathrm{C}$} & 0.000156 & 0.000401 & 0.388693 & 0.6975 \\
\hline & \multicolumn{4}{|c|}{ Variance Equation } \\
\hline $\begin{array}{l}\mathrm{C}(2) \\
\mathrm{C}(3) \\
\mathrm{C}(4) \\
\mathrm{C}(5)\end{array}$ & $\begin{array}{l}-0.001864 \\
-0.030788 \\
0.269153 \\
0.966240\end{array}$ & $\begin{array}{l}0.004918 \\
0.012788 \\
0.013475 \\
0.001341\end{array}$ & $\begin{array}{l}-0.379039 \\
-2.407595 \\
19.97365 \\
720.7954\end{array}$ & $\begin{array}{l}0.7047 \\
0.0161 \\
0.0000 \\
0.0000\end{array}$ \\
\hline $\begin{array}{l}\text { R-squared } \\
\text { Adjusted R-squared } \\
\text { S.E. of regression } \\
\text { Sum squared resid } \\
\text { Log likelihood } \\
\text { Durbin-Watson stat }\end{array}$ & $\begin{array}{l}-0.000014 \\
-0.000014 \\
0.605473 \\
87.25016 \\
-83.01485 \\
1.858163\end{array}$ & $\begin{array}{l}\text { Mean d } \\
\text { S.D. de } \\
\text { Akaike } \\
\text { Schwar } \\
\text { Hannan }\end{array}$ & $\begin{array}{l}\text { var } \\
\text { var } \\
\text { erion } \\
\text { n } \\
\text { riter. }\end{array}$ & $\begin{array}{l}-0.002092 \\
0.605469 \\
0.736526 \\
0.809255 \\
0.765834\end{array}$ \\
\hline
\end{tabular}

From table 3, the EGARCH model for interest rate (MPR), the p-values for the $\alpha$ and $\beta$ coefficient are 0.0161 and 0.0000 respectively, which shows that they are statistically significant at 0.05 level. (ie less than the level of significance). Thus $\mathrm{H}_{02}$ is rejected and $\mathrm{H}_{\mathrm{A} 2}$ accepted confirming that volatility in interest rates move in cluster. This is further affirmed by the sum of $\alpha$ and $\beta,-0.030788$ and $0.966240=0.935452$. This shows volatility clustering in interest rate and because the value of the sum $\alpha$ and $\beta$ coefficient is $<1$, it means that it will revert to its mean after a short time. The EGARCH model does not have the non-negativity condition unlike the GARCH model. Thus is very appropriate for the result.

\title{
5.2. Volatility Clustering in Inflation Rates
}

In order to test this hypothesis, the result of $\operatorname{GARCH}(1,1)$ model as shown in table 4 is used.

Table4. The Garch Model Result for Inflation Rate (Cpi)

\author{
Dependent Variable: D(CPI) \\ Method: ML ARCH - Normal distribution (BFGS / Marquardt steps) \\ Date: 09/07/16 Time: 23:10 \\ Sample (adjusted): 1995M02 2014M12 \\ Included observations: 239 after adjustments \\ Convergence achieved after 35 iterations \\ Coefficient covariance computed using outer product of gradients \\ Presample variance: backcast (parameter $=0.7$ ) \\ $\mathrm{GARCH}=\mathrm{C}(2)+\mathrm{C}(3)^{*} \mathrm{RESID}(-1)^{\wedge} 2+\mathrm{C}(4)^{*} \mathrm{GARCH}(-1)$
}


Macroeconomic Variables Volatility in the Nigerian Stock Market; An Empirical Analysis

\begin{tabular}{|c|c|c|c|c|}
\hline Variable & Coefficient & Std. Error & Z-Statistic & Prob. \\
\hline \multirow[t]{2}{*}{ C } & 0.572930 & 0.056523 & 10.13616 & 0.0000 \\
\hline & \multicolumn{4}{|c|}{ Variance Equation } \\
\hline $\begin{array}{l}\mathrm{C} \\
\operatorname{RESID}(-1)^{\wedge} 2 \\
\operatorname{GARCH}(-1)\end{array}$ & $\begin{array}{l}0.014893 \\
0.018217 \\
0.966348\end{array}$ & $\begin{array}{l}0.007423 \\
0.014430 \\
0.018409\end{array}$ & $\begin{array}{l}2.006395 \\
1.262473 \\
52.49426\end{array}$ & $\begin{array}{l}0.0448 \\
0.2068 \\
0.0000\end{array}$ \\
\hline $\begin{array}{l}\text { R-squared } \\
\text { Adjusted R-squared } \\
\text { S.E. of regression } \\
\text { Sum squared resid } \\
\text { Log likelihood } \\
\text { Durbin-Watson stat }\end{array}$ & $\begin{array}{l}-0.003787 \\
-0.003787 \\
0.897296 \\
191.6233 \\
-301.9594 \\
1.404134\end{array}$ & \multicolumn{2}{|c|}{$\begin{array}{l}\text { Mean dependent var } \\
\text { S.D. dependent var } \\
\text { Akaike info criterion } \\
\text { Schwarz criterion } \\
\text { Hannan-Quinn criter. }\end{array}$} & $\begin{array}{l}0.627930 \\
0.895601 \\
2.560329 \\
2.618513 \\
2.583776\end{array}$ \\
\hline
\end{tabular}

From table 4, the GARCH model result shows that the p-values for coefficient are 0.2068 for $\alpha$ and 0.0000 for the $\beta$, which implies that at 0.05 significant level, there is no ARCH effect and there is GARCH effect. This implies that, last month's conditional variance has significant impact on the current month's conditional variance. The sum of $\alpha$ and $\beta$ are $0.018217+0.966348=0.984565$. This implies that the inflation rate is volatile and moves in clusters, because the sum of $\alpha$ and $\beta<1$. It will revert to its mean after a long time. This is further affirmed by the large value of the GARCH coefficient $\beta 0.96634$, which is very close to 1 , and confirms that there is volatility clustering in inflation rate in Nigeria. Thus we reject $\mathrm{H}_{03}$.

\subsection{Findings}

The findings from the study are very significant and reveal the following:

1. Existence of high and persistence volatility in the stock market returns in Nigeria.

2. Interest rate revealed high volatility which reverts to the mean of the variance over a short time frame.

3. Inflation rate showed high volatility, that reverts to the mean of the variance equation in a short time frame.

\section{Conclusions}

The nexus between the stock market and macroeconomic variables has been a source of great concern for economy and financial researchers due to the significant role the stock market plays in enhancing economic growth and development of a country through mobilization and efficient direction of resources from surplus units to deficit units, however the persistence of high volatility in the market tends to trigger financial crashes and crisis, which could have an adverse effect on the economy and trigger a recession. The findings of, oseni and Nwosa (2011), Emenike 2010, Ezepue and Omar (2013) suggested the presence of excessive volatility in the Nigerian stock market.

The volatility in the Nigeria stock market returns is a double edged sword, volatility is the engine of the stock market and it is also generates the profit for investors, however what is of concern to investors is high stock market volatility, which causes stock market crashes and crisis, and result in huge financial losses for individual government, Institutional investors and other stakeholders.

The findings revealed that there is volatility clustering in the macroeconomic variables and persistent volatility in the dependent variable (stock market returns)

\section{RECOMMENDATIONS}

This paper made the following recommendations based the on results obtained:

1. The regulatory authorities should be foresighted to take proactive action that will minimize stock market return volatility in order to restore confidence in the market.

2. Securities and Exchange Commission (SEC) should engage more professionals that can develop models which will be used to predict the future of stock market return volatility and advise the regulatory authorities in good time to take the necessary step to present excessive volatility. 
3. Monetary Policy Committee (MPC) should regularly appraise their monetary policies. This will be a source of information that will drive the necessary policy changes, to minimize stock market volatility in Nigeria

4. The National Bureau of Statistics should make data on macroeconomic variable available to policy makers on weekly basis for effective and timely intervention policies that can slow stock market return volatility.

5. Investors should study the market and policy directions of the regulatory authorities, to enable them predict the direction of the stock market volatility and avoid the risk of volatility by investing in bonds and treasury bills.

6. The regulatory authorities should take steps to encourage more mutual funds to participate in the stock market as a way of stabilizing the market on the long run by creating incentives that will attract more private and public mutual funds.

7. The foreign direct investment( FDI) which is one of the major sources of financing stock market activities, and also a major source of high and persistent stock market volatility, should be directed towards the real sector, by providing the enabling environment and improve on the ease of doing business in the Nigerian business environment.

\section{REFERENCES}

[1] Adamopoulos, A. (2010). Stick Market and Economic Growth: An Empirical Analysis for Germany. Business and Economic Journal, 1-12.

[2] Andrew Thrasher (2017) forecasting a volatility Tsunami. SSRN https://ssrn.com/abstract= 2949847s

[3] Benjamin A. Abugari 2008, Emprical relationship between macroeconomics volatility and stock returns: Evidence from Latin American markets

[4] Chinzara .Z. (2011). Macro-economic uncertainty and conditional stock market volatility in South Africa. African Journal of economics 79, 27-49. http://dx.doi.org.//10.1111/J18136982.2011.01262.X

[5] Chinzara, Z., Aziakpono, M. J.(2009), Dynamic Returns Linkages and Volatility Transmission between South African and World Major Stock Markets. Working Paper No. 146

[6] Debes h Bhowmik 2013, Stock market volatility an International Journal of Scientific and Research

[7] Drimus Gabriel G. and Farkas, Walter, local volatility for VIX market (December 10, 2011). Review of Derivative Research 16(3), 267-293 (2013) available as SSRY https://ssrn.com/ abstract $=1970547$ or http://dx.doi.org/10.2139/ssrn.371461

[8] Emenike, K. O. A \&Aleke, S. F. (2012). Modeling asymmetric volatility in the Nigerian Stock exchange. European journal of Business and management, 4(12), 52-59.

[9] Goudarzi, H. \& Ramanarayanan, C. S (2011).Modeling asymmetric volatility in the Indian stock market. International journal of Business and management, 6(3), 221-231.

[10] Gupta R., Modise, M. P. (2011), Macroeconomics Variables and South African stock Return Predictability. Working paper in Nigeria Journal of international Review of management and Business

[11] Izuchukwu C. D, Ifurueze M. S. and Chude N. P. (2015), Impact of some selected Macroeconomic variables on stock market returns in Nigeria. International Journal of Economic and Business review vol. 3 issue 12 December 2015.

[12] John, K. M. K. and Owusu-Nantwi, V. (2013), Macroeconomic Variables and Stock Markets Returns: Full Information Maximum Likelihood Estimation. International Journal of Economics and management sciences, 3(6): 23-35.S

[13] Mukhopadhyay, D., Sarkar, N.(2003). Stock return and macroeconomic fundamentals in modelspecification framework: Evidence from Indian stock market. Indian Statistical institute, Economic Research Unit, ERU 2003-05 Discussion Paper, 2003, 1-28.

[14] Mushtaq, R., Shah, A. S. Z., Rehman, M. Z. U., and Murtaza, G. (2011).The V relationship between stock market volatility and macroeconomic volatility Evidence from Pakistan. Available at SSRN: Nigeria capital 
[15] Okpara, G. C (2011). Volatility modeling and the Nigerian stock returns relationship in EGARSH-in-mean framework. International Journal of Current Research, 3(8), 176-185.

[16] Onakoya Adegbemi Babatunde 2013, Stock market Volatility and Economic Growth

[17] Onwukwe, C. E., Bassey, B. E. E. \& Isaac, 1. 0. (2011). On modeling the volatiity of Nigerian stock returns using GARCIEI models. Journal of Mathematics Research, 3(4), 31-43.

[18] Oseni, I. O. \&Nwosa, P.I. (2011). Stock market volatility and macroeconomic variables volatility in Nigeria: An Exponential GARCH Approach. European Journal of Business and Management, 3(12), 43-53.

[19] Park, K., Ratti, R. A. (200). Real activity, inflation, stock returns, and monetary policy. Financial Review, 35, 59-78.

[20] Petros, J. (2011). The effect of the stock exchange on economic growth: A case of the Zimbabwe stock exchange. Research in business and Economics Journal. Publication, Volume3, Issue 10, October 2013 ISSN 200-3153ss

[21] Rano, A. S. U. (2010). Does inflation has an impact on stock returns and volatility? Evidence from Nigeria and Ghana. MPRA Munich paper No. 30091. research Vol2 issue.1

[22] Robert, D. G. (2008).Effect of Macroeconomic Variables on Stock Market Returns for four Emerging Economies: Brazil, Russia, India, and China. Retrieved in International Finance and Economic Journal.

[23] Schwert G. W: 1989, why does stock market volatility change overtime. Journal of Finance. 44(5) 1115-1153.

[24] Suleiman, Hamisu Kargi 20111, Stock Return and the volatility persistence in the

[25] Verma .S. and Mahajan .N. (2012). Stock returns volatility and the global Financial meltdown: The behavior of Indian stock market: International Journal of Art and Commerce vol. No.7

[26] Xiufangwang (2010). "The Relationship between Stock Market Volatility and Macroeconomic Economics, ISSN 1450-2887 Issue 49, Euro Journals Publishing, Inc.

[27] Zakamalin, kaleriy,Abnormal stock market Returns Around Peaks in VIX: the Evidence of investors over reaction (may 1 2016) Available at SSRN:https://ssrn.com/abstract $=2773134$ or http://dx.doi.org/10.2139/ssrn.2773134. 